\title{
ROZPRAWY
}

\author{
ADAM SOĆKO
}

\section{PROGRAMY HERALDYCZNE W DEKORACJI KOŚCIOŁÓW PARAFIALNYCH W KRAŚNIKU I CHODLU}

Późnogotycki kościół pw. Wniebowzięcia NMP w Kraśniku zawdzięcza dzisiejszy wygląd trzem zasadniczym kampaniom budowlanym, które już sto lat temu rozpoznali Adolf Szyszko-Bohusz i Marian Sokołowski1 $^{1}$ (il. 1a, 2). W pierwszej kolejności powstał ceglany, obszerny kaplicowy chór wraz z piętrową zakrystią. Kończono go zapewne w latach 40 . $\mathrm{XV}$ wieku, a inicjatywę budowy należy łączyć z dziedzicem Kraśnika, Andrzejem z Tęczyna zwanym Rabsztyńskim, herbu Topór oraz kraśnickim plebanem - Janem Kalińskim również pieczętującym się tym herbem. Zasługi plebana w tym względzie utrwalił żyjący wówczas Jan Długosz² Niewątpliwie w okresie budowy prezbiterium zamierzano realizację obszernego trójnawowego korpusu kościoła. Nie wiadomo jak zaawansowana była budowa w chwili tragicznej śmierci Andrzeja Tęczyńskiego w 1461 roku w czasie mieszczańskiego tumultu wynikłego po pobiciu przezeń krakowskiego płatnerza. Prawdopodobne jest jednak przypuszczenie Haliny Landeckiej, że finalizacja sklepionego korpusu kościoła wzniesionego z białych ciosów przypadła na czasy syna Andrzeja - Jana Tęczyńskiego (zm. 1498 lub 1499) kasztelana wiślickiego i najpewniej przypadła około 1469, kiedy to Jan zdecydował o powierzeniu opieki nad kościołem Kanonikom Regularnym Laterańskim sprowadzonym tu z podkrakowskiego Kazimierza $^{3}$ (il. 3). Jemu więc przypadła zasługa faktycznej fundacji klasztoru. Decyzję o powierzeniu zarządu parafii instytucji zakonnej, pierwszej na Lubelszczyźnie fundacji rodowej tego typu, miał

1 A. Szyszko-Bohusz, M. Sokołowski, Trzy kościoły halowe: Olkusz, Kraśnik, Kleczków, Sprawozdania Komisji do Badania Historii Sztuki w Polsce, t. 9, 1915, szp. 132-224, o Kraśniku szp. 158-210.

2 Ibidem, szp. $158-159$ oraz przypis 1 na s. 158.

${ }^{3}$ H. Landecka, Kościót parafialny pod wezwaniem Wniebowzięcia Najświętszej Marii Panny w Kraśniku - nowe ustalenia badawcze po I etapie badań - 2008-2009, „Budownictwo i Architektura" 7 (2010), s. 54. 

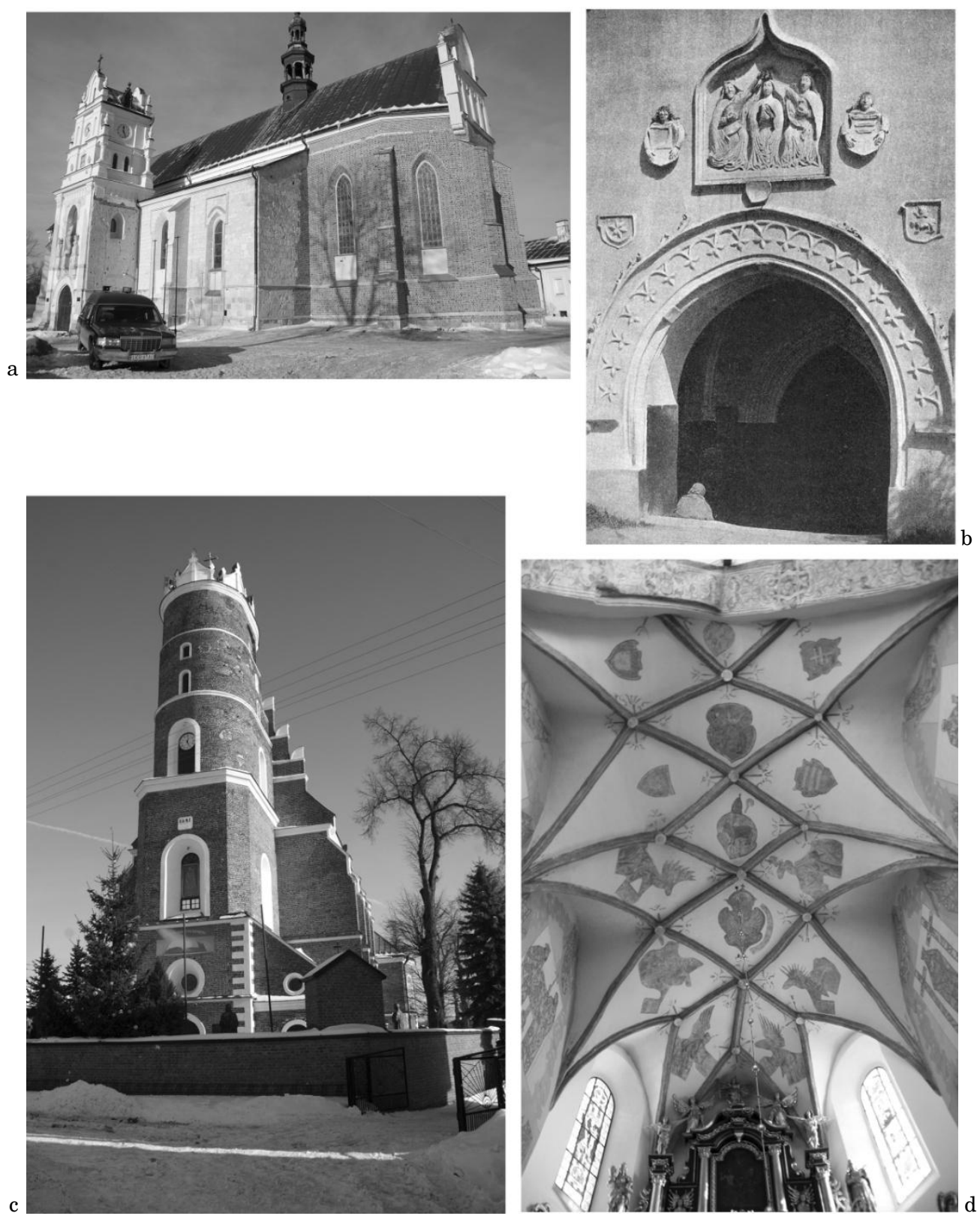

1. a) Kościół parafialny p.w. Wniebowzięcia NMP w Kraśniku, widok od pd. wsch., fot. autor; b) portal kruchty południowej kościoła parafialnego w Kraśniku, stan z końca XIX w., fot. wg: A. Szyszko-Bohusz, M. Sokołowski, op. cit.; c) Kościół parafialny pw. Trójcy Św. i Narodzenia NMP w Chodlu, widok od zach., fot. autor; d) Sklepienie prezbiterium kościoła parafialnego w Chodlu z polichromią heraldyczną, fot. autor 


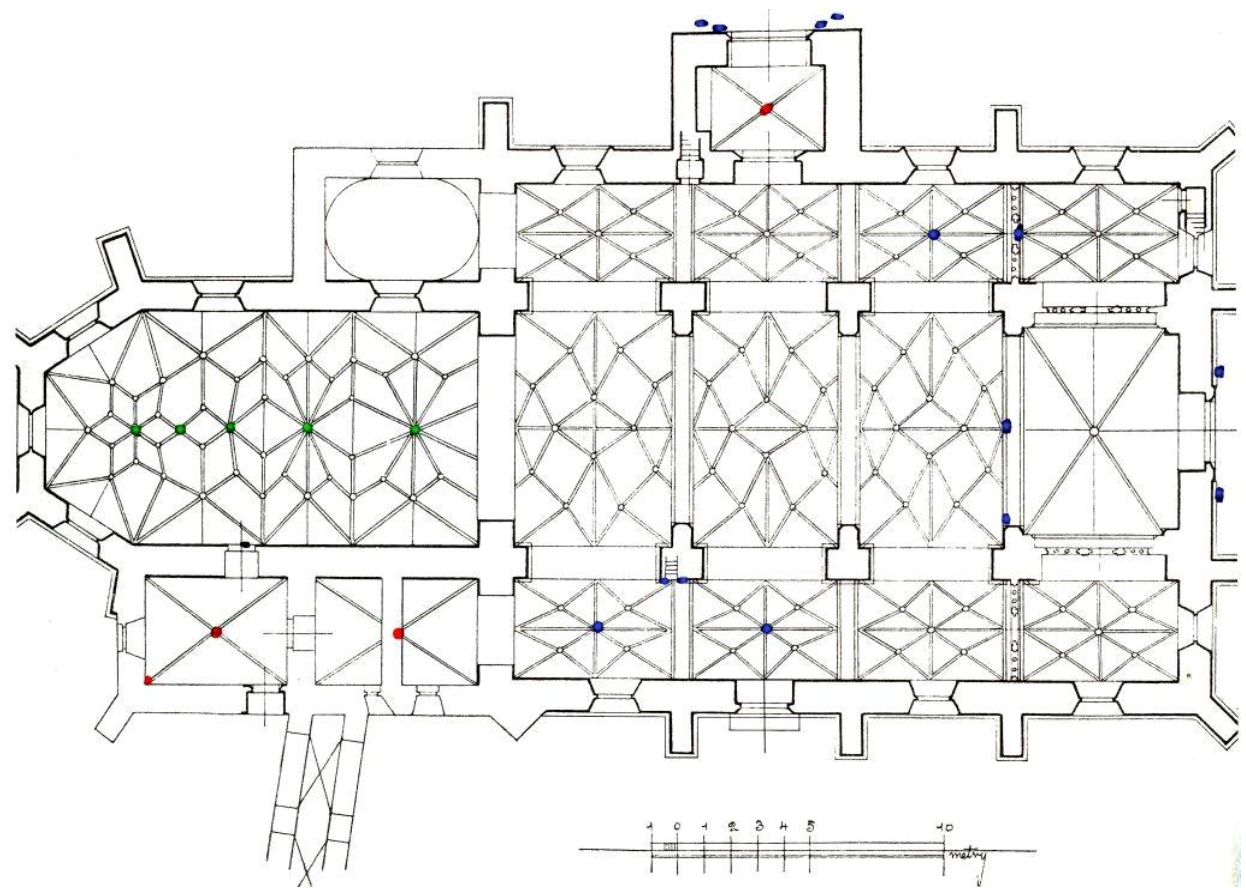

2. Rzut kościoła parafialnego w Kraśniku wg A Szyszko-Bohusz, M. Sokołowski, op. cit., z zaznaczonymi miejscami osadzenia herbów (opr. autor)

inspirować stryj i imiennik dziedzica Kraśnika, Jan Tęczyński (zm. 1470) kasztelan krakowski ${ }^{4}$. W rękach linii rodu zwanej Rabsztyńskimi Kraśnik pozostawał do 1510 roku. Rok wcześniej zmarł bezpotomnie ostatni jej męski przedstawiciel (Andrzej - kanonik krakowski) oraz Barbara z Konińskich, wdowa po Janie Tęczyńskim ${ }^{5}$. Wówczas to, drogą wykupu, $\mathrm{w}$ posiadanie miasta weszła linia Tęczyńskich z Morawicy, Tęczyna i Końskowoli. Dla obu rodzin - co okaże się istotne - wspólnym przodkiem był jednak pierwszy z Tęczyńskich władający Kraśnikiem - Andrzej (zm. 1411 lub 1412), kasztelan wojnicki, który z kolei wszedł w posiadanie miasta w 1407 lub 1408 roku poprzez małżeństwo z Anną, córką Dymitra z Goraja herbu Korczak ${ }^{6}$. Obie linie Tęczyńskich były więc związane z Kraśnikiem, obie były też spokrewnione z rodem Konińskich wywodzących się z Końskowoli. Kiedy więc w 1510 roku miasto kupowała

${ }^{4}$ A. Szyszko-Bohusz, M. Sokołowski, op. cit., szp. 158 (przypis 1, część 3), szp. 183.

5 Ibidem, szp. 184-185, J. Kurtyka, Tęczyńscy. Studium z dziejów polskiej elity możnowładczej w średniowieczu, Kraków 1997, tab. IV. Rabsztyńscy (6) i (2).

${ }^{6}$ A. Szyszko-Bohusz, M. Sokołowski, op. cit., szp. 181, J. Kurtyka, op. cit., tab. II. Potomkowie Nawoja z Morawicy (7). 


\section{TĘCZYŃSCY W KRAŚNIKU I ICH KOLIGACJE}

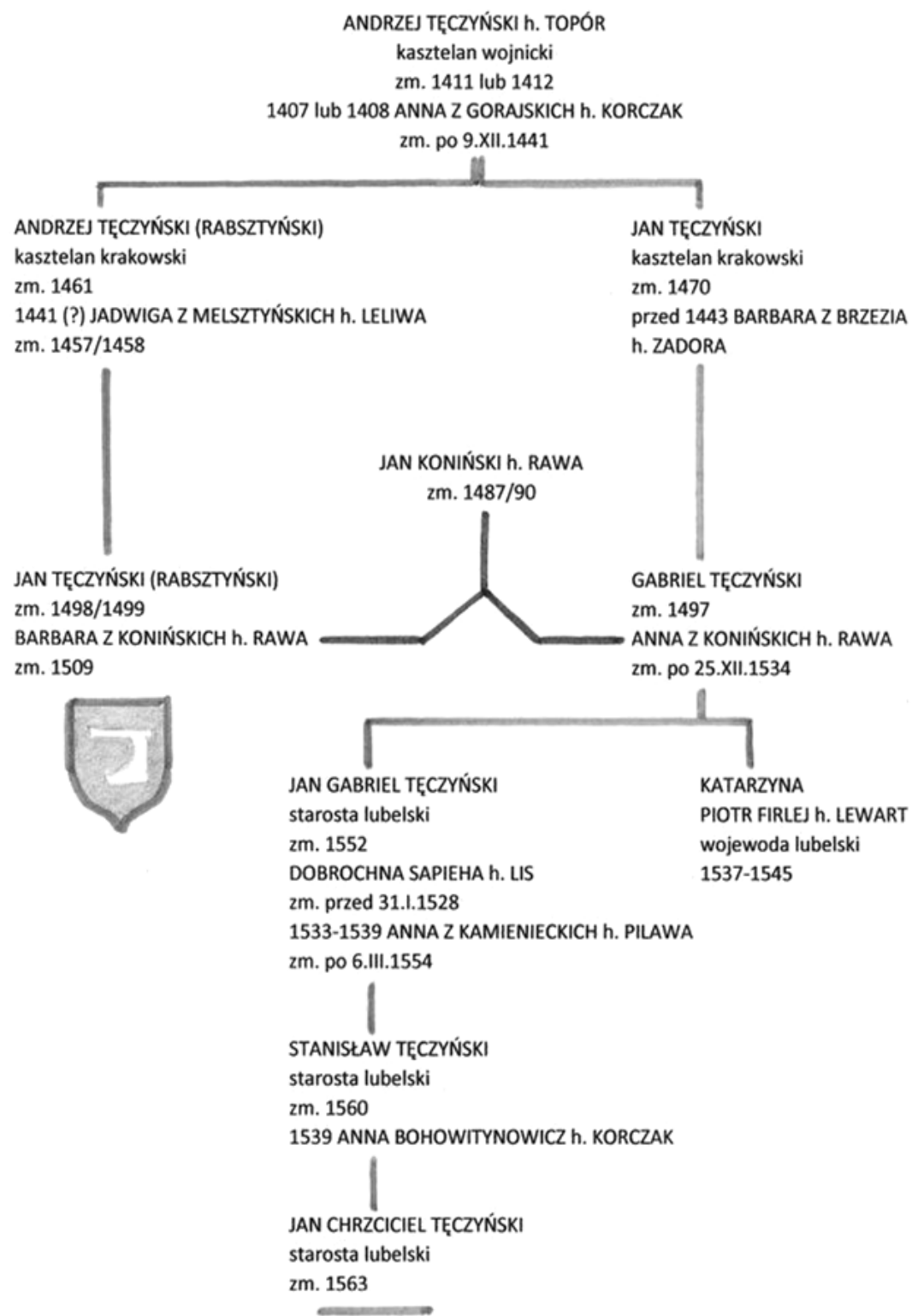

3. Uproszczony schemat genealogii Tęczyńskich herbu Topór - posesjonatów Kraśnika w XV-XVI w. 
z myślą o swych synach Anna Konińska, wdowa po Gabrielu Tęczyńskim z Morawicy, Tęczyna i Końskowoli, sprzedającymi były jej siostrzenice. Wkrótce po tej transakcji dziedzicem Kraśnika został Jan Gabriel Tęczyński, kasztelan wojnicki i starosta lubelski, zmarły w 1552 roku7 (il. 3). To on - jak sądzę, wraz z synem Stanisławem (zm. 1560) - był głównym inspiratorem przebudowy kościoła przypadającej na drugą ćwierć XVI stulecia ${ }^{8}$. Zasklepiono wówczas cały kościół - najpierw prezbiterium i nieco później korpus, w obu wypadkach zastępując sklepienia $\mathrm{XV}$-wieczne9 . Wówczas też dokonano przekształceń zachodniej partii kościoła, wznosząc obszerną emporę organową z dekoracyjnie opracowanym parapetem oraz organizując $w$ zachodnich przęsłach naw bocznych rodowe kaplice grobowe wydzielone ażurowymi, murowanymi przegrodami. Wtedy też (1541) zainstalowano kamienny portal u wejścia na ambonę oraz portal do zakrystii $(1543)^{10}$. Wiele wskazuje na to, że wtedy właśnie wzbogacono dekoracją heraldyczną elewację zachodnią i elewację kruchty południowej. To właśnie okres przebudowy z drugiej ćwierci XVI wieku jest szczególnie interesujący z punktu widzenia dekoracji heraldycznej. Jan Gabriel - a jak sądzę także Stanisław, jego syn - przekształcili kościół kraśnicki w reprezentacyjną nekropolię, nadając świątyni charakter memorii rodowej Tęczyńskich.

Zachowany bogaty zestaw herbów zintegrowanych z architekturą kościoła był jak dotąd analizowany jedynie przez Mariana Sokołowskiego i w niewielkim stopniu - przez Adolfa Szyszko-Bohusza ${ }^{11}$. Przy czym obaj badacze zbyli milczeniem trzy znaki herbowe widoczne na zwornikach korpusu i jeden na emporze zachodniej. Pozostawili też bez wyjaśnienia

7 A. Szyszko-Bohusz, M. Sokołowski, op. cit., szp. 186, J. Kurtyka, op. cit., tab. IIIa (27), Urzędnicy województwa lubelskiego XVI-XVIII wieku. Spisy, opr. W. Kłaczewski i W. Urban, red. A. Gąsiorowski, Kórnik 1991, s. 17, 22-23, 51.

8 O Stanisławie zob.: J. Kurtyka, op. cit., tab. IIIa (36), Urzędnicy..., s. 51.

${ }^{9}$ Katalog zabytków sztuki w Polsce, t. 8, Województwo lubelskie, red. R. Brykowski, E. Rowińska, Z. Winiarz, z. 9, Powiat kraśnicki, opr. I. Galicka, E. Rowińska, Warszawa 1961, s. 13.

10 Portal prowadzący do zakrystii, z wykutą inskrypcją - cytatami ze Starego Testamentu oraz czytelną datą: 1543, w Katalogu zabytków sztuki w Polsce (s. 14) został opisany jako struktura z 2 ćwierci XVI wieku z nieczytelną inskrypcją fundacyjną. Być może jego ówczesny stan zachowania uniemożliwiał odczytanie nieznanej, dotąd nie opublikowanej daty.

11 A. Szyszko-Bohusz, M. Sokołowski, op. cit., passim: artykuł autorstwa obydwu badaczy zawiera generalnie fragmenty opisu i analizy architektury pióra Adolfa SzyszkoBohusza oraz rozważania natury historyczno-genealogicznej pióra Mariana Sokołowskiego. Komentarze i przypisy tego ostatniego pojawiają się jednak także w napisanej zapewne nieco wcześniej części Szyszko-Bohusza. We wszystkich późniejszych publikacjach informacje na temat herbów kraśnickich mają charakter odtwórczy. 
wyjątkową odmianę herbu Topór - z ostrzem skierowanym w dół, występującą w tej postaci rzadko, choć nie wyłącznie w Kraśniku12. Herby eksponowane są do dziś w czterech zespołach: w przestrzeni zakrystii, w prezbiterium (na zwornikach sklepienia), w korpusie nawowym (na zwornikach sklepienia naw bocznych, na parapecie empory zachodniej, na portalu ambony i na przegrodzie kaplicy południowej) oraz na elewacjach zewnętrznych - ponad wejściem od strony południowej prowadzącym przez kruchtę oraz ponad portalem i oknem w fasadzie zachodniej (il. 2). To właśnie program heraldyczny posłużył badaczom sprzed stu lat do określenia datowania XVI-wiecznej przebudowy kościoła. Spotykany bowiem trzykrotnie we wnętrzu czteropolowy herb Tęczyńskich o dwóch polach z toporem na krzyż z orłem dwugłowym mógł zostać przywołany w Kraśniku nie wcześniej niż w 1527 roku, czyli z chwilą jego ustanowienia na znak nadania Tęczyńskim tytułu hrabiowskiego przez Karola V (il. 5e,f). Z kolei wykuta na portalu ambony data 1541 od stu lat jest uważana za orientacyjny czas zakończenia przebudowy (il. 5d). Powszechnie przyjęto więc, że etap wczesnorenesansowej przebudowy przypadał pomiędzy latami 1527 a $1541^{13}$.

Najstarsze, XV-wieczne, są trzy herby w zakrystii. Dwa z nich - Korczak i Topór osadzono w zwornikach dwóch przęseł aneksu (il. 4a,b). Topór powtórzono także na jednym wsporniku - ponad nadprożem dawnego kominka (il. 4c). Herb Korczak odnosi się bezsprzecznie do Anny, córki Dymitra z Goraja, która wniosła miasto w posagu Andrzejowi

12 Tak np. na płycie nagrobnej kanonika Stanisława Sławińskiego z około 1550, zachowanej w katedrze we Włocławku - Katalog zabytków sztuki w Polsce, t. 11, Dawne województwo bydgoskie, red. Tadeusz Chrzanowski, Marian Kornecki, z. 18, Włocławek i okolice, opr.: Wanda Puget, Tadeusz Chrzanowski, Marian Kornecki, Warszawa 1988, s. 25, fig. 339.

13 Tak: A. Szyszko-Bohusz, M. Sokołowski, op. cit., szp. 166, 170; Katalog zabytków..., s. 11, A. Biedroń, Kraśnik: kościót par. p.w. Wniebowzięcia Panny Marii i św. Augustyna, kanoników regularnych, (w:) Architektura gotycka w Polsce, red. T. Mroczko, M. Arszyński, Katalog zabytków, red. A. Włodarek, Warszawa 1995, s. 131, H. Landecka, op. cit., s. 55; S. Gołub, Kościót pw. Wniebowzięcia Najświętszej Marii Panny w Kraśniku - wyniki badań archeologicznych, (w:) Kościoły, cerkwie i klasztory Lubelszczyzny w świetle badań archeologicznych, red. E. Banasiewicz-Szykuła, Lublin 2013, s. 11; R. Karpińska, Z kart historii miasta i kościoła, (w:) Kościót Wniebowzięcia Najświętszej Marii Panny w Kraśniku, red. J. Zamorski, Kraśnik 2013, s. 16 - gdzie autorka osadza przebudowę w dłuższym okresie 1527-1561. Odosobniony i nie do utrzymania jest pogląd Michała Kurzeja przyjęty następnie przez Zbigniewa Banię, jakoby późnogotyckie sklepienie korpusu kościoła powstało dopiero około 1580 roku, być może za sprawą lubelskiego muratora Rudolfa Negroniego zob.: M. Kurzej, Archaizacja i modernizacja. Przemiany stylowe dekoracji sklepiennych na przykładzie kościoła i klasztoru SS. Brygidek $w$ Lublinie, „Roczniki Humanistyczne”, t. 54, z. 4, 2006, s. 154, Z. Bania, Architektura, (w:) Sztuka polska. Wczesny i dojrzaly barok (XVII wiek), Warszawa 2013, s. 79. 


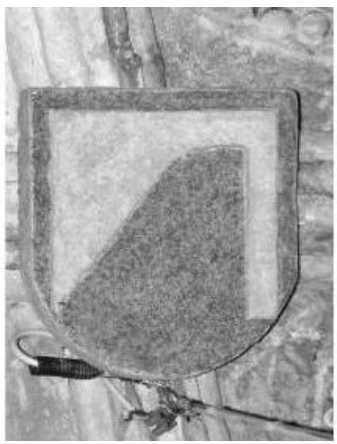

a

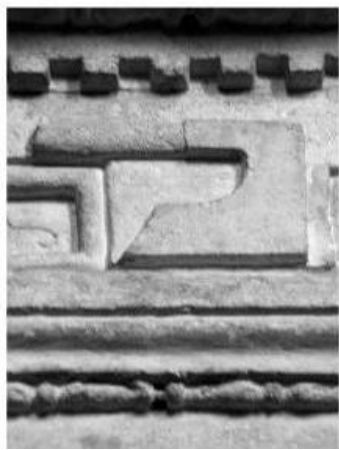

d

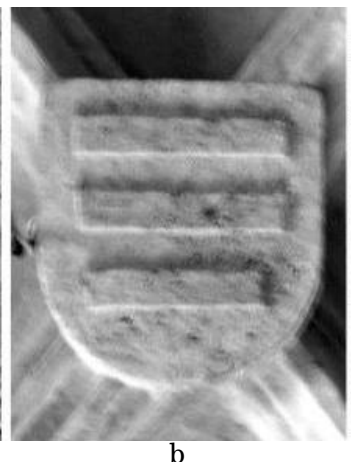

b

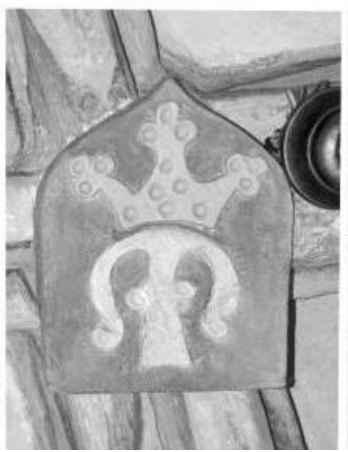

e

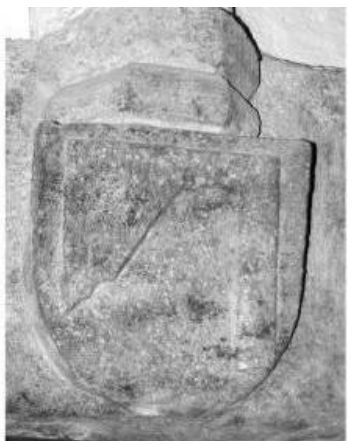

C

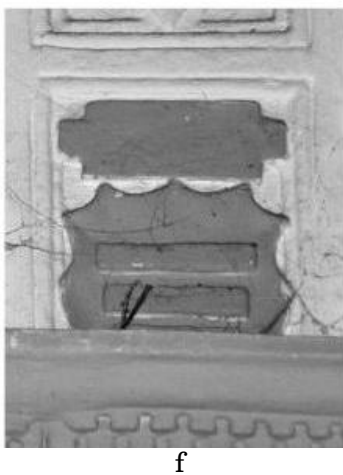

4. Kraśnik, kościół parafialny p.w. Wniebowzięcia NMP: a) herb Topór na zworniku sklepienia zakrystii, b) herb Korczak na zworniku sklepienia zakrystii, c) herb Topór na wsporniku sklepienia zakrystii - nad kominkiem, d) Topór - godło herbowe Tęczyńskich na nadprożu portalu zakrystii, 1543 r., e) inicjał Maryjny na odwróconej tarczy herbowej na zworniku sklepienia kruchty pd., f) herb Korczak na parapecie empory zachodniej

Tęczyńskiemu, kasztelanowi wojnickiemu. Topór na sklepieniu powinien więc odnosić się do jej męża - zmarłego raptem w trzy czy cztery lata po ślubie, w 1411 bądź 1412 roku14 lub jej syna, Andrzeja, zwanego Rabsztyńskim - domniemanego inicjatora budowy murowanego prezbiterium. Topór znad kominka upamiętnia najpewniej plebana Jana Kalińskiego, którego zasługi dla budowy uwiecznił Jan Długosz. Wszystkie trzy herby są trwale zintegrowane ze strukturą sklepienia i pochodzą z czasów budowy chóru i zakrystii, najpewniej z lat 40. XV wieku. Przywołanie herbu Anny z Gorajskich jest ważnym argumentem wskazującym, że budowa wschodniej partii kościoła ruszyła jeszcze za jej życia, czyli przed 9 grudnia 1441 roku, kiedy wzmiankowano o niej po raz ostatni ${ }^{15}$.

14 J. Kurtyka, op. cit., tab. II. Potomkowie Nawoja z Morawicy (7).

15 Ibidem. 

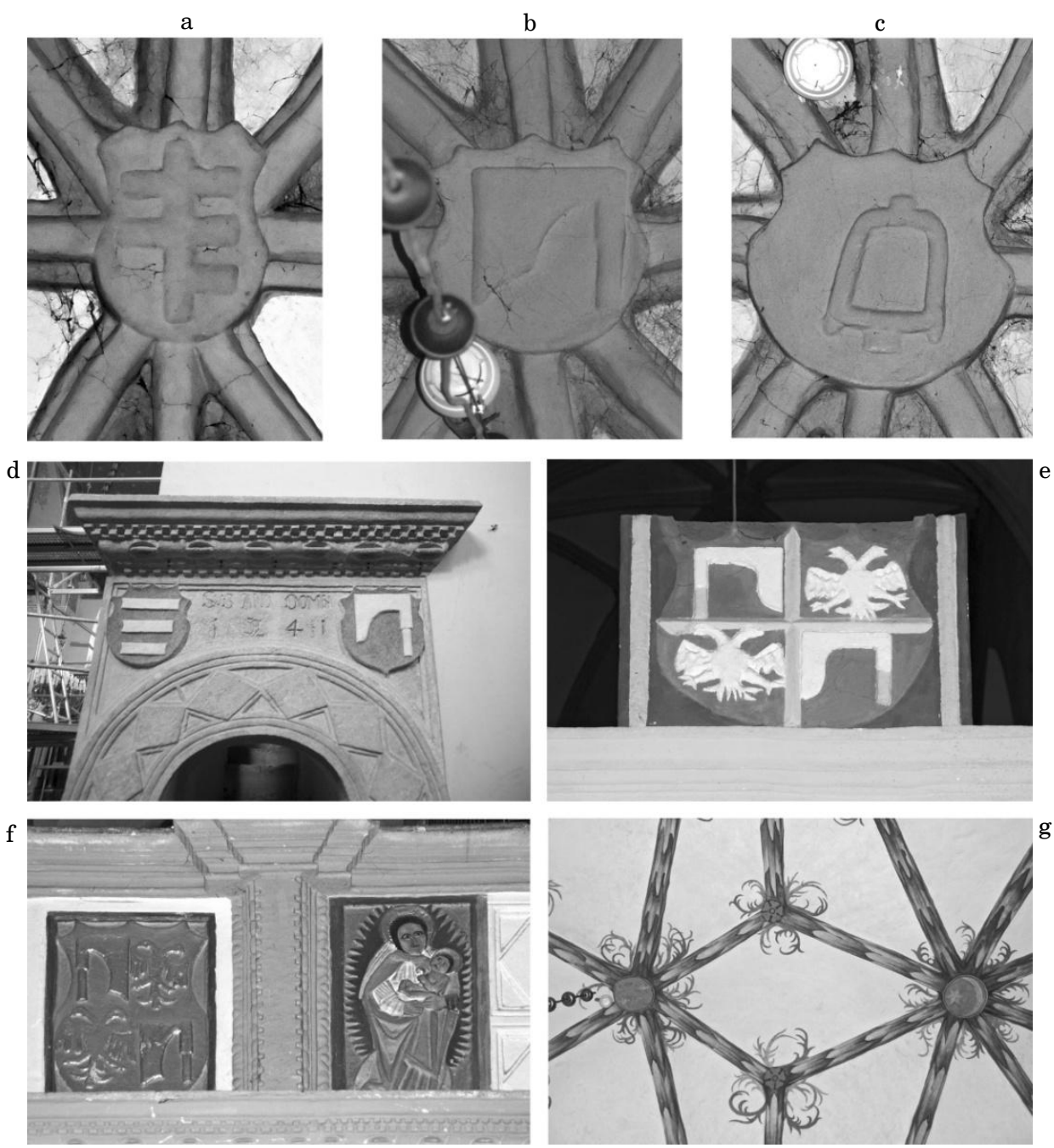

5. Kraśnik, kościół parafialny p.w. Wniebowzięcia NMP: a) herb Pilawa na zworniku sklepienia nawy pn., b) herb Topór na zworniku sklepienia nawy pn., c) herb Strzemię na zworniku sklepienia nawy pd., d) herby Korczak i Topór w zwieńczeniu portalu ambony, $1541 \mathrm{r}$., e) herb Tęczyńskich (hrabiowski) na przegrodzie kaplicy pd.-zach., f) herb Tęczyńskich (hrabiowski) i wizerunek Marii z Dzieciątkiem na parapecie empory zach., g) zworniki sklepienia prezbiterium (fragment) - widoczne herby Tęczyńskich (hrabiowski) i Leliwa

Bardziej skomplikowana jest sytuacja znaków herbowych na zwornikach prezbiterium (il. 5g). Sklepienie powstało być może już na samym początku XVI wieku'16. Ale zworniki nie odzwierciedlają stanu z tego cza-

${ }^{16}$ Czas powstania sklepienia, uznawanego za nieco starsze od tego w korpusie, sytuowano zwykle w drugiej ćwierci XVI wieku. Po najnowszych odkryciach - ujawnieniu ma- 
su. Pierwsze od wschodu pole dawniej dekorowała tarcza z monogramem ukoronowanej litery $\mathrm{M}$ - znak ideowy odnoszący się - ponad ołtarzem do patronki świątyni i jej niebiańskiego triumfu. Widzieli ów znak jeszcze Adolf Szyszko-Bohusz i Marian Sokołowski17. Dziś znak ten zaginął i przez konserwatorów został zastąpiony - nie wiedzieć czemu - herbem Topór. Pojęcie o wyglądzie zaginionego zwornika oddaje jednak zachowany in situ analogiczny znak w zwieńczeniu sklepienia kruchty południowej kościoła, integralnie związany z przedsionkiem, a zatem powstały około 1469 roku lub nieco wcześniej (il. 4e). W dalszej kolejności ku zachodowi na zwornikach chóru przedstawiono następujące herby: Jelita, Topór (czteropolowy), Leliwa i Korczak (il. 5g). Prawdopodobnie obecny wygląd podwieszone zworniki uzyskały dopiero w XVII wieku. Na ich wtórność wskazywał już Adolf Szyszko-Bohusz ${ }^{18}$. Przemawia za tym kilka argumentów. Przede wszystkim - obecność herbu Jelita jest uzasadniona dopiero po 1604 roku, kiedy dobra Kraśnickie nabyli Zamoyscy, włączając je w skład ordynacji. Poza tym - zamiast tarcz herbowych zworniki przyjmują nowożytny kształt płaskich podwieszonych dekli inny niż zachowane tarczowe zworniki z XV i XVI wieku. Wreszcie sklepienie nosi wyraźne ślady nowożytnych przekształceń. Na ile jednak ów układ może stanowić odzwierciedlenie pierwotnego? Pozostawmy odpowiedź na to pytanie na później.

Najwięcej uwagi badacze heraldyki kościoła kraśnickiego poświęcili kompozycji herbów towarzyszących płaskorzeźbie Koronacji Najświętszej Marii Panny ulokowanej na ścianie kruchty południowej. Pierwotnie rzeźba umiejscowiona była w niszy zamkniętej łukiem oślego grzbietu tuż ponad wejściem do przedsionka kościoła (il. 1b). Po nadbudowie kruchty w latach 1907-1917 do formy wieżowej zarówno sama rzeźba, jak i towarzyszące jej herby zostały wmurowane znacznie wyżej. Zmianie uległ kształt dawnej niszy z kompozycją Koronacji Marii. Przy jej dolnej krawędzi do początku XX wieku znajdowała się niewielka tarcza herbowa zapewne z malowanym - już wówczas nieczytelnym znakiem - może ukoronowanym monogramem maryjnym. Przekształcenia z okresu nadbu-

lowanej inskrypcji fundacyjnej na ścianie wschodniej prezbiterium z 1512 roku oraz daty konsekracji ołtarza głównego w 1506 roku, trzeba poważnie rozważyć datowanie sklepienie w okresie tuż przed 1512 rokiem - zob.: E. Zielińska, M. Rogowska, D. Szulc, Odkrycia poczynione podczas remontu, (w:) Kościót Wniebowzięcia Najświętszej Marii Panny w Kraśniku, Kraśnik 2013, s. 63-67 (E. Zielińska).

${ }_{17}$ A. Szyszko-Bohusz, M. Sokołowski, op. cit., szp. 162.

18 Ibidem. Szczególnie podejrzanie wygląda hrabiowski herb Tęczyńskich, bowiem Topór umieszczono nieprawidłowo w 2 i 3 polu tarczy, a powinien być w polu 1 i 4 . Nie wiem też, jak wytłumaczyć powód wzbogacenia herbu Korczak o formę półksiężyca widoczną poniżej trzech wrębów. 
dowy kruchty nie wpływają jednak na identyfikację zachowanych herbów szlacheckich, choć zmieniono relacje $\mathrm{w}$ ich wzajemnym rozmieszczeniu. Po ostatniej konserwacji kościoła herby ustawiono względem siebie w pozycji znanej z fotografii i opisów sprzed 1907 roku (il. 6b). Adolf Szyszko-Bohusz i Marian Sokołowski widzieli w zestawie czterech herbów odwołanie do osoby i koligacji głównego fundatora klasztoru - Jana Tęczyńskiego, kasztelana wiślickiego (il. 3). Reprezentuje go herb Topór tu jednak $\mathrm{w}$ tej niespotykanej gdzie indziej odmianie - $\mathrm{z}$ ostrzem skierowanym w dół19. Tarczę herbową dzierży herold. Po drugiej stronie reliefu odpowiada jej analogiczne przedstawienie z herbem Korczak - odnoszącym się do babki ojczystej Jana - Anny z Gorajskich. Poniżej, w płasko wykutej tarczy wmurowanej w elewację przedstawiono herb Rawicz - odnoszący się niewątpliwie do żony Jana Tęczyńskiego - Barbary z Konińskich, wreszcie poniżej herbu Tęczyńskich osadzono herb Leliwa - odnoszący się do Jadwigi Ksiąskiej, córki Jana z Melsztyna - matki Jana. $\mathrm{Z}$ uwagi na identyfikację ideową programu z Janem Tęczyńskim, fundatorem klasztoru, przyjęto, że herby powstały w czasie budowy tej partii kościoła i w okresie fundacji klasztoru, czyli około 1469 roku $^{20}$.

Sądzę, że było inaczej: herby umieszczono później, zapewne około 1540 roku z inicjatywy Jana Gabriela Tęczyńskiego - pierwszego dziedzica linii rodu związanej z Końskowolą. Przemawia za tym wiele argumentów. Po pierwsze - charakter stylowy dekoracji: prymitywna rzeźba Koronacji Marii, sposób formowania draperii szat, heroldowie trzymający tarcze, wykrój pierwotny płyciny o zamknięciu w ośli grzbiet - znacznie trafniej jest odnosić te cechy do drugiej ćwierci XVI niż trzeciej XV wieku. Po drugie - wykrój tarcz herbowych o wklęsłej powierzchni i wklęsłych odcinkach krawędzi w zestawie herbów kraśnickich znajduje analogie wyłącznie w herbach XVI-wiecznych (na sklepieniach naw bocznych, emporze zachodniej i przegrodzie kaplicy południowo-zachodniej i na portalu ambony) (il. 4f, 5a-f), podczas gdy herby zworników dowodnie XV-wiecznych mają klasyczny kształt tarcz - bez wklęsłości i wciętych krawędzi (sklepienie zakrystii, zwornik kruchty południowej) (il. 4a-c, e). Po trzecie - tarcze herbowe trzymane przez heroldów żywo przypominają aranżację kafli heraldycznych $\mathrm{z}$ drugiej ćwierci XVI wieku, na przykład tych

19 A. Szyszko-Bohusz, M. Sokołowski, op. cit., szp. 174. Przywołanie poprzez herby postaci Jana Tęczyńskiego w kontekście wizerunku Koronacji Marii ma uzasadnienie także z tego względu, że właśnie w związku z jego decyzją o powierzeniu opieki nad kościołem kanonikom regularnym zmieniono wezwanie świątyni na Maryjne.

20 Ibidem; R. Karpińska, Domina Nostra, (w:) Kościót Wniebowzięcia Najświętszej Marii Panny w Kraśniku, red. J. Zamorski, Kraśnik 2013, s. 27. 

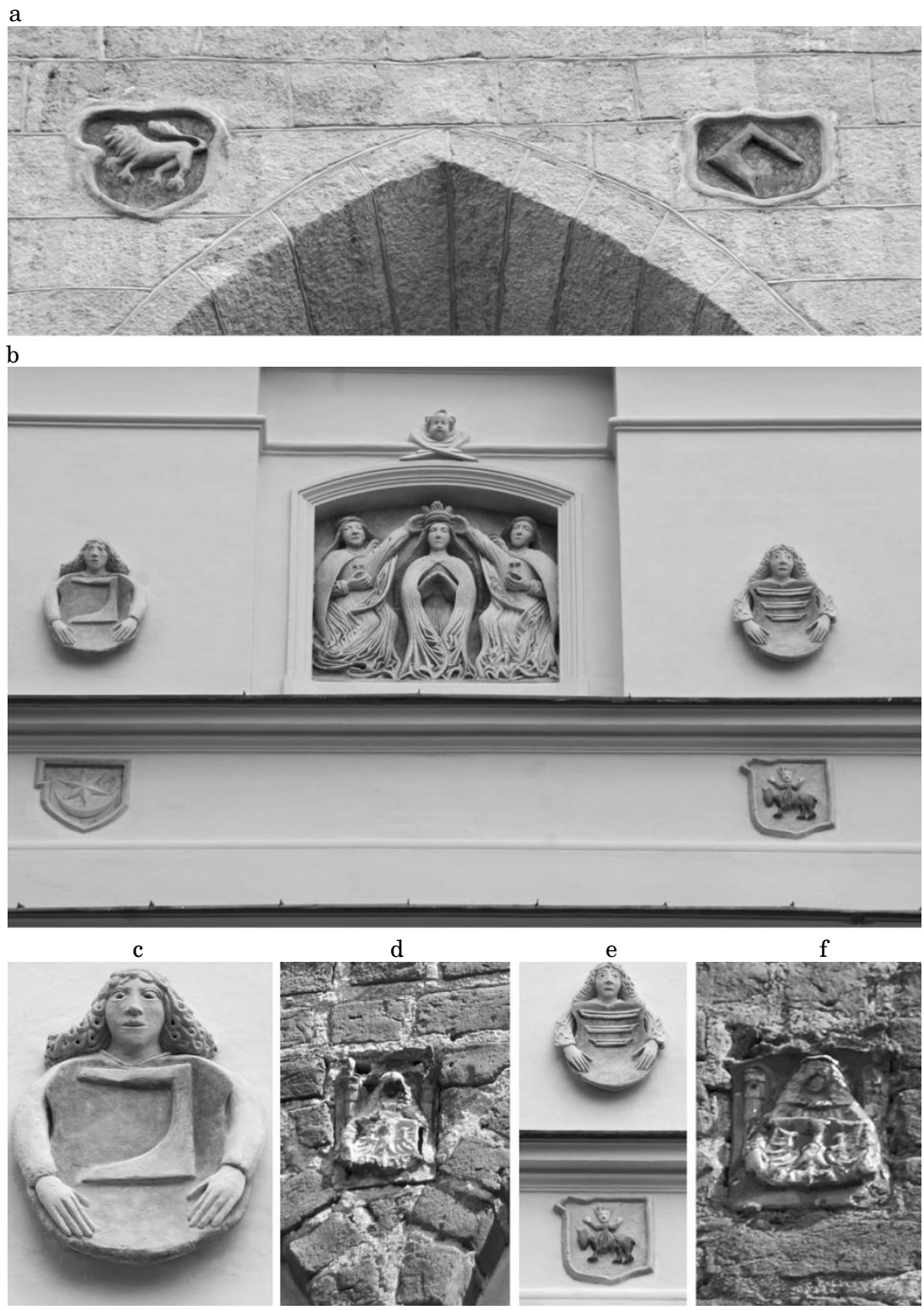

6. a) Kraśnik, kościół parafialny, herby Lewart i Topór w partii zwieńczenia okna fasady zach., b) Kraśnik, kościół parafialny, płaskorzeźba ze sceną Koronacji Marii w otoczeniu herbów: Topór, Korczak, Leliwa, Rawa - osadzone wtórnie w górnej partii wieżowego pawilonu kruchty pd., c) Kraśnik, herb Topór z elewacji kruchty pd., d) Kodeń, kafel heraldyczny wmurowany w szczyt zach. dawnej cerkwi zamkowej, e) Kraśnik, herby Korczak i Rawa na elewacji pd. Kruchty, f) Kodeń, kafel heraldyczny wmurowany w szczyt zach. dawnej cerkwi zamkowej 
wmurowanych w szczycie cerkwi zamkowej w Kodniu'21 (il. 6d, f). Po czwarte - przyjęcie XVI-wiecznej metryki tej dekoracji pozwala wytłumaczyć logicznie sens zastosowanej tu odmiany herbu Topór z ostrzem skierowanym w dół. Sądzę, że taka redakcja znaku herbowego nie jest przypadkiem i z perspektywy projektodawcy programu herbowego z czasów Jana Gabriela Tęczyńskiego miała oznaczać wymarłą gałą́ rodu Tęczyńskich - Rabsztyńskich (il. 3). W konsekwencji - XVI-wieczne herby Topór z klasycznie ukazanym godłem daje się połączyć z żyjącymi członkami rodu z linii Gabriela z Morawicy, Tęczyna i Końskowoli.

Jak dotąd, nikt nie zaproponował wyjaśnienia tak nietypowej modyfikacji herbu Tęczyńskich prezentowanego $\mathrm{z}$ ostentacją na fasadzie kruchty południowej. Marian Sokołowski ograniczył się tylko do stwierdzenia, że odmiany tej nie znał Franciszek Piekosiński22. Natomiast w opracowaniu Józefa Szymańskiego herb w tej odmianie prezentuje wyłącznie ilustracja, podczas gdy brak jakiejkolwiek próby wyjaśnienia genezy tej odmiany ${ }^{23}$. Za proponowanym tu wyjaśnieniem przemawiaja jeszcze dwie okoliczności. Opracowane analogicznie względem dolnej pary z kruchty południowej herby nad oknem fasady zachodniej - Lewart i Topór - można połączyć wyłącznie z postaciami żyjącymi w drugiej ćwierci XVI wieku [il. 6a]. Identyfikacja tych herbów nie doczekała się dotąd zadowalającego wyjaśnienia. Marian Sokołowski przypuszczał, że przedstawienie lwa na tarczy herbowej nie jest wizerunkiem herbu Lewart, bowiem nie potrafił wskazać na jakikolwiek związek z Kraśnikiem

21 Cerkiew kodeńska została wzniesiona w drugiej ćwierci XVI wieku, może około 1530 roku - zob. A. Siemaszko, Kodeń, Cerkiew zamkowa p.w. św. Mikołaja, (w:) Architektura gotycka $w$ Polsce, red. T. Mroczko, M. Arszyński, Katalog zabytków, red. A. Włodarek, Warszawa 1995, s. 108-109. O jej stylistycznym związku z kościołem kraśnickim przesądza niemal identyczna koncepcja struktury i dekoracji sklepień (wykonanych jednak mniej starannie) i renesansowych, odcinkowych wsporników, analogiczna struktura podpór oraz pokrewny detal kamieniarski. Podobieństwa te nie są kwestią przypadku. Inicjator budowy cerkwi, dziedzic Kodnia - Paweł Sapieha, wojewoda nowogrodzki, był szwagrem Jana Gabriela Tęczyńskiego. Wprawdzie jego siostra, Dobrochna, pierwsza żona Tęczyńskiego zmarła w 1528 roku lub nieco wcześniej, ale rodzinne relacje zapewne przetrwały dłużej, tym bardziej, że nie wiadomo kiedy dokładnie Tęczyński zawarł drugi związek małżeński (najpóźniej w roku 1539). Jest bardzo prawdopodobne, że obaj inwestorzy zatrudnili ten sam zespół wykonawców działających na Lubelszczyźnie na przestrzeni lat 30. i 40. XVI wieku. Z uwagi na opisane okoliczności do myślenia daje także fakt, że wmurowane $\mathrm{w}$ formie dekoracyjnej aplikacji w szczycie cerkwi renesansowe kafle $\mathrm{z}$ herbem królestwa dzierżonym przez heroldów są, pomimo różnicy skali i techniki wykonania, niemal identyczne względem górnej pary herbów (Topór i Korczak) dekorujących kruchtę kościoła w Kraśniku.

22 A. Szyszko-Bohusz, M. Sokołowski, op. cit., szp. 174, przypis 2.

23 J. Szymański, Herbarz średniowiecznego rycerstwa polskiego, Warszawa 1993, s. 277-279; Idem, Herbarz rycerstwa polskiego z XVI wieku, Warszawa 2001, s. 293-295. 
pieczętujących się tym znakiem Firlejów. Uznał on, że lew na tarczy jest jak gdyby wyabstrahowanym znakiem środkowej tarczy herbu hrabiowskiego Tęczyńskich, który zmienił swój wygląd w związku z kolejną modyfikacją z 1561 roku $^{24}$. Herby z fasady zachodniej miałyby więc zaistnieć dopiero po tej dacie! Tymczasem odnoszą się one niewątpliwie do małżonków Piotra Firleja oraz Katarzyny Tęczyńskiej. Katarzyna była siostrą Jana Gabriela - inicjatora XVI-wiecznej przebudowy kościoła, a Piotr Firlej z Dąbrowicy w czasie przekształceń kościoła kraśnickiego był wojewodą lubelskim (il. 3). Nominację na ten urząd uzyskał w czerwcu 1537 ro$\mathrm{ku}$, a w kwietniu 1545 roku awansował na województwo ruskie ${ }^{25}$. Czas sprawowania najwyższego urzędu w województwie przez szwagra Jana Gabriela, który z kolei od 1530 roku aż do śmierci dzierżył starostwo lubelskie ${ }^{26}$, był wystarczającym i zapewne głównym powodem manifestacji w programie fasady związku Tęczyńskich z Firlejami. W ten sposób program herbowy na elewacjach kościoła ukazywał powiązania Tęczyńskich z najznaczniejszymi rodami i dygnitarzami Lubelszczyzny XV i początków XVI wieku.

Przyjmując hipotetycznie, że odmiana herbu z ostrzem skierowanym w dół oznacza wymarłą linię Tęczyńskich z Kraśnika, można też zrozumieć, dlaczego godło herbu Topór oznaczającego Katarzynę Tęczyńską na fasadzie zachodniej zostało widocznie pochylone (il. 6a). Być może jest to znak, że żeński przedstawiciel nie zapewni kontynuacji rodu Toporczyków. Na korzyść tej hipotezy wyjaśniającej modyfikacje wizerunku herbowego Tęczyńskich przemawia także godło herbu Topór, tym razem bez tarczy - wprowadzone właśnie w odmianie $\mathrm{z}$ pochylonym $\mathrm{w}$ dół ostrzem - w zwieńczeniu portalu zakrystii kościoła (il. 4d). Portal wmurowano w 1543 roku, na co wskazuje wykuta na nim data. Prowadzi on do zakrystii, której program herbowy odnosił się przecież do wymarłej linii Tęczyńskich. Z kolei inskrypcja odkuta na ościeżach portalu nie jest stricte inskrypcją fundacyjną, jak określono ją w Katalogu zabytków sztuki $w$ Polsce ${ }^{27}$, lecz zawiera cytaty z Księgi Psalmów oraz II Księgi Kronik odnoszące się do domu Jahwe i budowy świątyni Salomona. W tym sensie, na zasadzie analogii, odnoszą się one do materialnej budowli kościoła kraśnickiego, ale w warstwie aluzyjnej pewnie także do domu Toporczyków ${ }^{28}$. Dlatego właśnie inskrypcja z portalu zakrystii przypomina zasługi

${ }^{24}$ A. Szyszko-Bohusz, M. Sokołowski, op. cit., szp. 179.

25 J. Kurtyka, op. cit., tab. IIIa (33); Urzędnicy..., s. 57 (nr 367).

${ }^{26}$ Urzędnicy..., s. 51 ( $\left.\mathrm{nr} 312\right)$.

${ }^{27}$ Katalog zabytków..., t. 8, z. 9, s. 14.

28 Tekst inskrypcji z portalu: PSALM XXV DOMINE DILEXI DECOREM DOMVS TUE ET LOCVM HABITACIONIS GLORIE TVE [godło topór] ANNO DOMINI 1543 II 
inicjatorów budowy kraśnickiego kościoła z wymarłej już linii Rabsztyńskich. W odniesieniu do portalu zakrystii warto tylko wspomnieć, że właśnie w pobliżu takich wejść często umieszczano inskrypcje dotyczące czasu i okoliczności fundacji lub konsekracji kościołów oraz programy heraldyczne związane $\mathrm{z}$ dobrodziejami świątyń. Tak więc i w tym wypadku posłużenie się godłem Topora o zwróconym ku dołowi ostrzu znajduje silne uzasadnienie ${ }^{29}$.

Pozostają wreszcie do rozszyfrowania herby $\mathrm{z}$ wnętrza korpusu, istotne z punktu widzenia datowania XVI-wiecznej przebudowy. Czterech z nich nie dostrzegli monografiści kościoła kraśnickiego. Pozostałe wydawały się mieć oczywistą wymowę i nie poświęcono im wiele uwagi. Badacze sprzed wieku nie dostrzegli trzech herbów wykutych na zwornikach sklepienia naw bocznych. W pierwszym od wschodu przęśle nawy północnej osadzono po raz kolejny herb Topór - w klasycznej wersji (il. 5b). W zworniku drugiego od wschodu przęsła tej samej nawy towarzyszy mu herb Pilawa (il. 5a). W genealogii Tęczyńskich tego czasu herb Pilawa może oznaczać wyłącznie drugą żonę inicjatora przebudowy kościoła, Jana Gabriela Tęczyńskiego. Była nią Anna z Kamieńca córka Jana, kasztelana lwowskiego, wdowa po Stanisławie Spinku z Będkowa. Ślub z Tęczyńskim zawarła po 29 maja 1533 roku a przed 10 lutego 1539 roku. Anna przeżyła drugiego męża o dwa lata, zmarła po 6 marca 1554 roku $^{30}$. $\mathrm{Z}$ faktu umieszczenia jej herbu w sąsiedztwie herbu Topór wynika jedno - sklepienie nie było gotowe przed 1533 rokiem. Można też przypuszczać, że gdyby jakikolwiek związek $\mathrm{z}$ procesem rozbudowy kościoła miała pierwsza żona Jana Gabriela, Dobrochna, córka Jana Sapiehy z Kodnia, to i jej herb (Lis) znalazłby miejsce w strukturze świątyni kraśnickiej. Dobrochna zmarła prawdopodobnie niedługo przed 31 stycznia 1528 ro$\mathrm{ku}^{31}$. A zatem przebudowa świątyni kraśnickiej ruszyła nie wcześniej niż

PALI VIII ELEGI ET SANCTIFICAVI MICHI LOCUM ISTUM IN SEMPITERNUM czyli (psalm): „Jahwe, miłuję dom, w którym mieszkasz, i miejsce gdzie przebywa Twa chwała. Roku Pańskiego 1543". Odwołanie do fragmentu z Księgi Kronik $(7,16)$ jest skrótem frazy: „elegi enim et sanctificavi locum istum, ut sit nomen meum ibi in sempiternum, et permaneant oculi mei et cor meum ibi cunctis diebus” (Vulgata) i znaczy: „wybrałem i uświęciłem ten mój dom na wieki" - tłumaczenie wg.: Pismo Święte Starego i Nowego Testamentu (Biblia Tysiąclecia), Poznań-Warszawa 1971, s. 591 i s. 397.

${ }_{29}$ Aspekt ten omówiłem w innym miejscu - zob.: A. Soćko, Układy emporowe $w$ architekturze państwa krzyżackiego, Warszawa 2005, s. 229-230.

30 J. Kurtyka, op. cit., tab. IIIa (27).

31 Ibidem. Dobrochna była córką Jana Sapiehy - założyciela Kodnia oraz siostrą Pawła Sapiehy, który wzniósł na zamku cerkiew i ufundował ojcu w 1520 roku prymitywną, dziś wmurowaną nad wejściem, płytę nagrobną niemal w całości określającą genealogiczne powiązania Sapiehów. 
u schyłku lat dwudziestych. Bardziej prawdopodobne jest jednak datowanie przebudowy na schyłek lat 30. XVI wieku.

Jedynym znakiem, którego obecności w kościele nie potrafię wyjaśnić, jest herb Strzemię, wykuty na zworniku drugiego od zachodu przęsła nawy południowej (il. 5c). Możliwe, że odnosi się on do któregoś z prepozytów klasztoru pełniącego urząd w trakcie XVI-wiecznej przebudowy.

Wreszcie kilka słów należy się najlepiej eksponowanym herbom Topór i Korczak odkutym ponad wejściem na ambonę. Nie budziły one większego zainteresowania badaczy. Z tego elementu wystroju kościoła kraśnickiego najważniejsza wydawała się bowiem wykuta inskrypcja z datą: „sub anno domn 1541” uznawana za poświadczenie momentu ukończenia przebudowy kościoła (il. 5d). Powodem braku szczegółowych dociekań co do tej pary herbów jest fakt, że analogiczne zestawienie pojawiało się w świątyni kilkakrotnie - w zakrystii, na sklepieniu prezbiterium i na fasadzie kruchty południowej. Wszędzie zestaw tych herbów uznawano za odnoszący się do Anny Gorajskiej i Andrzeja Tęczyńskiego, żyjących w początkach XV wieku. Jest to możliwe - herby z ambony odnosiłyby się wówczas do pradziadków fundatora XVI-wiecznej przebudowy. Herby na filarze ambony odkuto ewidentnie w 1541 roku. Nie wiadomo jednak, jaki sens miałoby umieszczanie daty rocznej $1541 \mathrm{w}$ sąsiedztwie herbów osób zmarłych przed przeszło stu laty? Rozwiązanie tej sytuacji okazuje się całkiem banalne, jeśli przyjąć, że herby oznaczają osoby żyjące w 1541 roku. Wówczas Topór oznaczałby syna Jana Gabriela - Stanisława Tęczyńskiego (zm. 1560), wówczas starostę urzędowskiego i parczewskiego, później wojewodę krakowskiego i dziedzica Kraśnika. Przed 26 sierpnia 1538 roku poślubił on Annę, córkę Bohusza Bohowitynowicza herbu Korczak. I to do nich zapewne należy odnieść herby zdobiące oprawę wejścia na ambonę 32 (il. 3).

Niedostrzeżony przez Adolfa Szyszko-Bohusza herb Korczak zdobi też jeden ze skrajnych paneli parapetu empory zachodniej (il. 4f). W tej części kościoła w oczy rzucał się wyłącznie reprezentacyjny herb hrabiowski Tęczyńskich, czteropolowy, osadzony na osi empory w towarzystwie wizerunku Matki Boskiej z Dzieciątkiem (il. 5f). Relief figuralny wykonano w bardzo prymitywnym stylu korespondującym zresztą z przedstawieniem Koronacji Marii z kruchty południowej. Dużo łatwiej było kamieniarzowi wykonać płaskie odwzorowania tarcz i godeł niż wizerunek postaci ludzkiej. Herbowi Korczak towarzyszyła zapewne jakaś data lub inskrypcja umieszczona na niewielkiej płytce osadzonej powyżej tarczy herbowej. Obecności tego herbu na emporze zachodniej - w miejscu, które często $\mathrm{w}$ średniowieczu łączono $\mathrm{z}$ ideą uobecnienia prestiżu fundatora

32 Ibidem, Tab. IIIa (36). 
i opiekuna instytucji kościelnej, w strefie budowli, którą przekształcono w rodową nekropolię, i której rangę podkreślało dwukrotne posłużenie się monumentalnymi wizerunkami herbu czteropolowego hrabiów Tęczyńskich (il. 5e,f) - trudno byłoby uzasadnić odwołaniem do osoby Anny, córki Dymitra z Goraja żyjącej w pierwszej połowie XV stulecia. Herb Korczak oznacza tu najpewniej osobę żyjącą, związaną z inicjatywą modernizacji kościoła w XVI wieku. Warunki te spełnia synowa Jana Gabriela - głównego, ale najwyraźniej nie jedynego inicjatora XVI-wiecznej przebudowy kościoła (il. 3). Wedle tego, co mówią herby, w inicjatywie budowlanej współuczestniczyli także Stanisław Tęczyński i Anna Bohuszowa. Kto wie, czy data 1541 odkuta przy ich herbach osadzonych na wejściu na ambonę nie jest datą narodzenia ich jedynego syna - Jana Chrzciciela, ostatniego z dziedziców Tęczyńskich w Kraśniku, który zakończy żywot bezpotomnie w 1563 roku w duńskiej niewoli?

Na koniec rozważań kraśnickich - zgodnie z zapowiedzią - przychodzi jeszcze powrócić do wtórnie aranżowanego zestawu herbów na zwornikach prezbiterium. Obecność herbu Jelita Zamoyskich przekonuje, że jakimś modyfikacjom zestaw ten został poddany w wieku XVII ${ }^{33}$. Trzeba się liczyć zarówno z wymianą znaków herbowych, jak i przemieszczeniem podwieszonych dekoracji. Intencją tego zestawienia była chęć upamiętnienia dobrodziejów kraśnickiego klasztoru. Program tej partii formułowany był zapewne z pozycji prepozytów tutejszego zgromadzenia. Dlatego herb Korczak może odnosić się tak do Anny z Gorajskich, współfundatorki najstarszej partii kościoła, jak i Anny Bohuszowej, której zasługi dotyczyły XVI-wiecznej przebudowy. Herb Leliwa miałby oznaczać Jadwigę z Melsztyńskich - żonę Andrzeja Tęczyńskiego-Rabsztyńskiego, głównego inwestora budowy części prezbiterialnej. Hrabiowski herb Tęczyńskich (mógł się pojawić po 1527 roku) - stanowił odwołanie do Jana i Stanisława Tęczyńskich żyjących w XVI wieku i wówczas prowadzących przebudowę kościoła (il. 5g). XVII-wieczny herb Jelita Zamoyskich zastąpił pewnie jakiś starszy znak. Najpewniej był nim herb Rawicz przynależny Barbarze Konińskiej, żonie Jana Tęczyńskiego - fundatora klasztoru. Gdyby przyjąć takie założenie, to wówczas zestaw herbów w prezbiterium powtarzałby konfigurację z fasady kruchty. Domniemanie o zastąpieniu herbu Rawicz herbem Zamoyskich też ma swoje uzasadnienie. Linia Rawitów z Końskowoli wygasła bowiem na początku XVI wieku wraz ze śmiercią dwóch sióstr - małżonek braci stryjecznych - Jana (z Kraśnika) i Gabriela (z Morawicy, Tęczyna i Końskowoli)34 (il. 3). Pamięć o Ko-

${ }^{33}$ A. Szyszko-Bohusz, op. cit., szp. 162.

${ }^{34}$ A. Sochacka, Przed nadaniem prawa miejskiego, (w:) Dzieje Końskowoli, red. R. Szczygieł, Lublin 1988, s. 34. 
nińskich - Rawitach z Końskowoli w XVII wieku była już nadwątlona, a nowy kolator (Zamoyski) musiał przecież zostać odpowiednio uhonorowany.

MACIEJOWSCY W CHODLU IICH KOLIGACJE

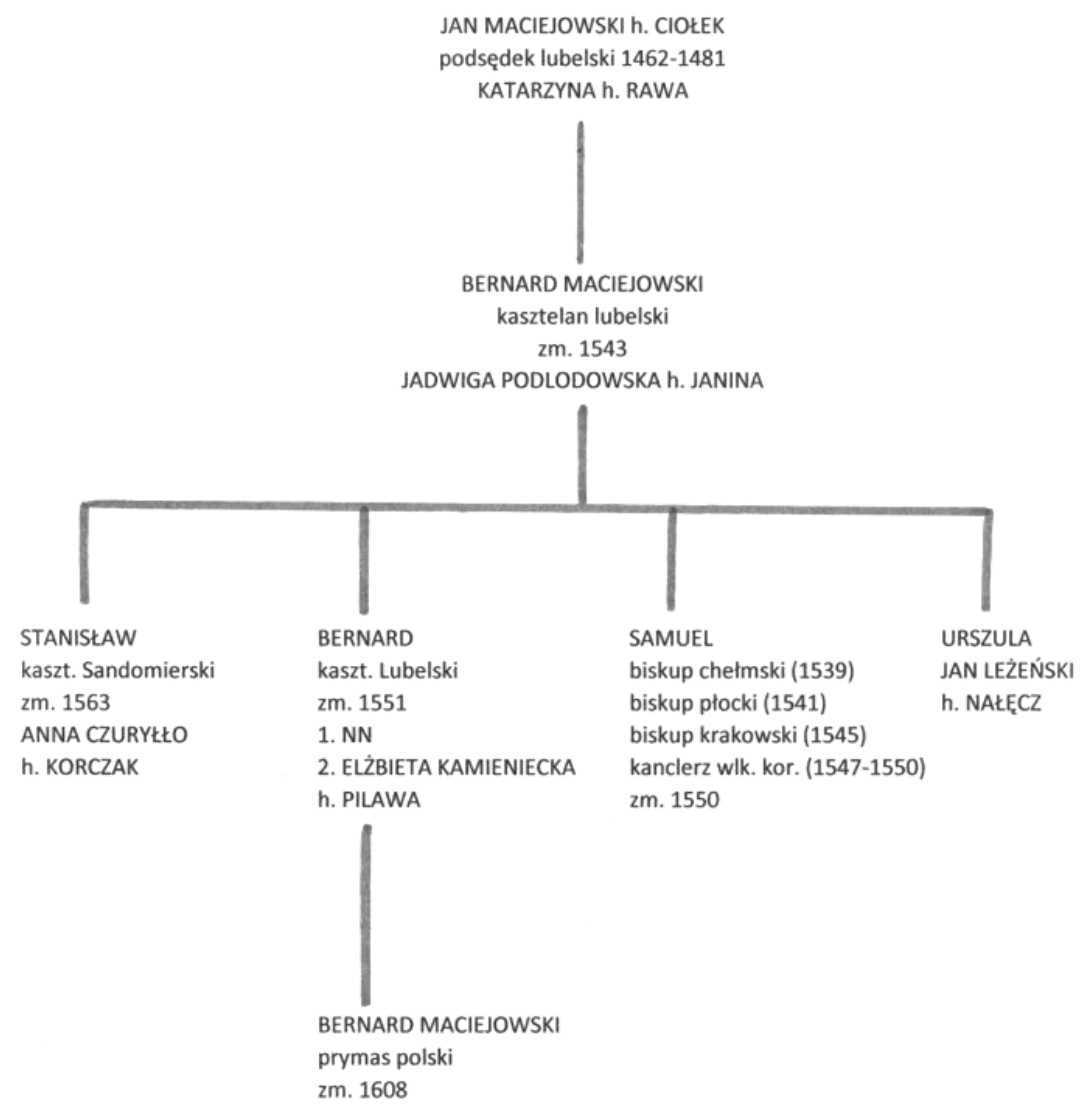

7. Uproszczony schemat genealogii Maciejowskich herbu Ciołek - posesjonatów Chodla w XVI w. (opr. autor)

Z przedstawionej powyżej analizy programu heraldycznego integralnie związanego z architekturą kościoła wynika kilka obserwacji, które mogą się okazać istotne dla uściślenia datowania XVI-wiecznej przebudowy. Przede wszystkim - wydaje się, że najbardziej stosownym momentem dla wprowadzenia herbów na fasadzie zachodniej był okres pełnienia 
przez Piotra Firleja urzędu wojewody lubelskiego, czyli lata 1537-1545. Przy okazji warto zaznaczyć, że monumentalny szczyt zachodni (odtworzony podczas ostatniej konserwacji kościoła), zdobiony płycinami zamkniętymi łukiem oślego grzbietu, mógł powstać dopiero w XVI stuleciu, gdy zasklepiano kościół, a nie - jak dotąd sądzono - około 1470 roku $^{35}$. Uobecnienie herbu Pilawa na sklepieniu nawy północnej, upamiętniającego Annę z Kamieńca - sytuuje czas budowy sklepienia najwcześniej na okres po 1533. Jeśli jednak do jej ślubu z Janem Gabrielem doszło bliżej 1539 roku, to i zasklepienie kościoła trzeba sytuować odpowiednio później. Wreszcie najmłodszą datą dowodnie związaną $\mathrm{z}$ wczesnorenesansową przebudową kościoła kraśnickiego jest ta odkuta na portalu prowadzącym do zakrystii, dotąd ignorowana - czyli rok 1543. Znamienne, że tak znakomity i oczywisty argument ewidentnie przemawiający za nieznacznym odmłodzeniem wczesnorenesansowej przebudowy kościoła nie został dotąd dostrzeżony. Układ herbów na zwornikach prezbiterium ma zaś wtórny charakter i jest najpewniej świadectwem modernizacji tej partii w połowie XVII wieku. Z uwagi na powyższe konstatacje wydaje się, że przyjmowany dotąd na lata 1527-1541 jako czas wczesnorenesansowych przekształceń kościoła należy nieznacznie skorygować. Przebudowę przeprowadzono najpewniej w okresie od około 1537 do 1543 roku.

W czasie, gdy w Kraśniku podjęto wczesnorenesansową modernizację kościoła, w oddalonym na północ o 20 kilometrów Chodlu - miasteczku lokowanym w 1517 roku i stanowiącym odtąd ośrodek prywatnych dóbr rodziny Maciejowskich na Lubelszczyźnie, budowano manierystyczny kościół parafialny ${ }^{36}$ (il. 1c). Budowla ta jest jedną z najciekawszych struktur w regionie i jednocześnie jedną z najsłabiej poznanych. Możliwe, że budowę kościoła murowanego rozpoczęto tu już w latach 30. XVI wieku, najpóźniej stało się to $\mathrm{w} 1541 \mathrm{roku}^{37}$. Za inicjatora budowy uchodzi Ber-

35 Zachowane nad nawami bocznymi półszczyty (część środkowa nad nawą główną została zrekonstruowana $\mathrm{w}$ toku ostatniej konserwacji prowadzonej w latach 2007-2013) w zgodnej ocenie badaczy powstały w wieku XV - zob.: A. Szyszko-Bohusz, M. Sokołowski, op. cit., szp. 163-166, 169; A. Biedroń, op. cit., s. 131; H. Landecka, op. cit., s. 58 (szczyt z fazy budowlanej z ok. 1460). Jak dotąd nikt nie zakładał późniejszej metryki szczytu, tymczasem za taką możliwością zdaje się przemawiać oryginalna, późnogotycka dekoracja w postaci smukłych blend zamkniętych łukiem oślego grzbietu i wysublimowane, ustawione skośnie lizeny przechodzące górą w sterczyny. Bardziej prawdopodobne wydaje mi się przyjęcie XVI-wiecznej chronologii szczytu zachodniego - ok. 1540 roku.

${ }^{36}$ Katalog zabytków..., t. 8, z. 1, Powiat bełżycki, Warszawa 1960, s. 3; zob. też: www. barbaragolofit.republika.pl/chodel.html (dostęp: 29.08.2014).

37 Ibidem. 
nard Maciejowski (zm. 1543), kasztelan lubelski, założyciel miasta ${ }^{38}$, ale ciężar ukończenia świątyni spadł na jego dzieci - a zwłaszcza na pełniącego wówczas wysokie dystynkcje - Samuela (il. 7). Dzisiejszy kształt kościół uzyskał jeszcze przed połową XVI wieku. W każdym razie, najpewniej właśnie w samym końcu lat 40. pomiędzy żebrami późnogotyckiego sklepienia prezbiterium wprowadzono renesansową malowaną dekorację heraldyczną odnoszącą się do założycieli miasta i dobrodziejów kościoła (il. 1d). W Katalogu zabytków sztuki w Polsce dekoracja ta została określona jako aktualnie odkrywana i datowana na połowę XVI wie$\mathrm{ku}^{39}$. O ile wiem, nigdy dotąd nie opublikowano prób jej odczytania.

W trzech, wydzielonych żebrami, romboidalnych polach na osi sklepienia, od wschodu ku zachodowi wymalowano następujące herby: Orzeł Biały, ukoronowany zamkniętą koroną, Ciołek - zwieńczony infułą i pastorałem oraz Rawa. W ostatnim, niewielkim polu na osi graniczącym z łukiem tęczy na tarczy namalowano nie zidentyfikowany mniejszy od herbów gmerk. W części wschodniej dominuje herb królewski w otoczeniu sześciu aniołów trzymających księgi. Z kolei po bokach herbów usytuowanych na osi znajdują się herby zwrócone ku nim, jak gdyby w ukłonie heraldycznym. Są to - po stronie południowej: Korczak i Pilawa, po stronie północnej: Poraj i Janina. Program heraldyczny w kościele dopełnia odkuty na zworniku kruchty zachodniej herb Ciołek z wprowadzonymi na pole tarczy ponad godłem insygniami władzy biskupiej - infułą i pastorałem (il. 1d, 8a-c).

Orzeł Biały na sklepieniu chóru stanowi znak odnoszący się bezpośrednio do osoby panującego króla - Zygmunta Augusta, bowiem figurę orła opinają dwie litery: znacznych rozmiarów litera „S” oraz niewielka, umieszczona na piersi ptaka litera „A”. Jako oznaczenia imion Sigismundus Augustus stanowią one podstawowy argument dla datowania malowideł na czas po śmierci Zygmunta Starego, czyli po 1 kwietnia 1548 roku (il. 8b). Datę ante quem można wyznaczyć dzięki przywołaniu w zwieńczeniu herbu Maciejowskich insygniów biskupich. W tym czasie mogą one oznaczać wyłącznie Samuela Maciejowskiego, zmarłego 26 października $1550 \mathrm{roku}^{40}$ (il. 8a). Malowidła powstały więc najprawdopodobniej pomiędzy kwietniem 1548 a październikiem 1550 roku.

${ }^{38}$ Katalog zabytków..., t. 8, z. 1, s. 3; H. Kowalska, Maciejowski Bernard h. Ciołek (zm. 1543), (w:) Polski Słownik Biograficzny, t. 19/1, z. 80, Wrocław-Warszawa-Kraków... 1974, s. $47-48$.

${ }^{39}$ Katalog zabytków..., t. 8, z. 1, s. 4.

40 W. Dworzaczek, Maciejowski Samuel h. Ciołek (1499-1550), (w:) Polski Stownik Biograficzny, t. 19/1, z. 80, Wrocław-Warszawa-Kraków... 1974, s. 64-69. 

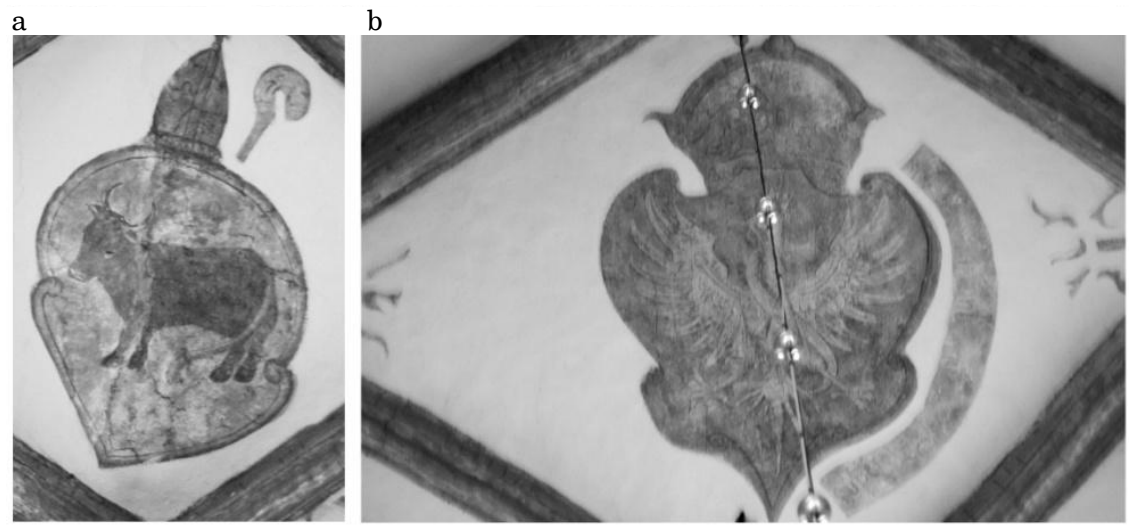

c

d
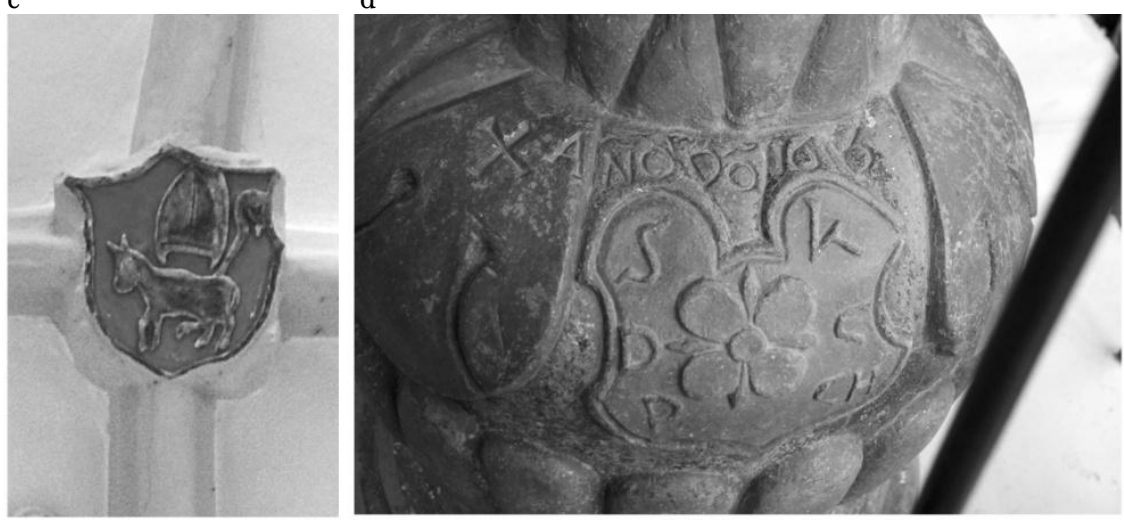

8. Chodel, kościół parafialny: a) herb Ciołek - polichromia sklepienia prezbiterium, b) herb królewski Zygmunta Augusta (z monogramem SA) - polichromia sklepienia prezbiterium, c) herb Ciołek z insygniami władzy biskupa Samuela Maciejowskiego - zwornik sklepienia w kruchcie zach., d) chrzcielnica z 1616 roku ufundowana przez Stanisława Korzeniowskiego h. Poraj.

Samuel Maciejowski, który zapewne wziął na siebie główny ciężar budowy kościoła41, od 1539 roku był biskupem chełmskim, od 1541 -

${ }^{41}$ Swoją wymowę ma w tym względzie umieszczenie na sklepieniu w przyziemiu wieży herbu Ciołek z określającymi godność biskupa Samuela infułą oraz pastorałem - analogicznymi względem malowanego herbu w prezbiterium. Pośrednio znak ten świadczy, że budowa kościoła - przynajmniej w partii przyziemia wieży, musiała być realizowana nie wcześniej niż w październiku 1539 roku, kiedy Samuel uzyskał prowizję na biskupstwo chełmskie. Podobnie jak w Kraśniku, tak i w Chodlu, zgodnie z dawną średniowieczną praktyką, wykorzystano zachodnią partię kościoła do demonstrowania zasług fundatora kościoła. W Chodlu aspekt ten wspiera dodatkowo monumentalna wieża będąca symbolem feudalnego władztwa Maciejowskich nad ich miastem. Samuel Maciejowski jest znany jako jeden z czołowych przedstawicieli humanizmu XVI wieku w Polsce, a jego zasługi funda- 
płockim, a od października 1545 roku - krakowskim. Wielką karierę zawdzięczał wsparciu tak Zygmunta Starego, jak i jego syna, za którego sprawą objął biskupstwo krakowskie. Był bliskim i zaufanym współpracownikiem obu Jagiellonów. Uwieńczeniem jego kariery było objęcie urzędu kanclerza wielkiego - w kwietniu 1547 roku. Powodem szczególnej próby lojalności Samuela wobec młodego króla był jego niewzruszony stosunek wobec małżeństwa Zygmunta Augusta z Barbarą Radziwiłłówną. Maciejowski uparcie bronił decyzji i autorytetu młodego króla przeciw silnej frakcji senatorów podburzanych przez królową matkę - Bonę Sforza. Dowodem uznania króla wobec kanclerza i biskupa były zabiegi monarchy czynione w kurii rzymskiej o nadanie Maciejowskiemu godności kardynalskiej. Starania te zniweczyła śmierć Samuela Maciejowskiego ${ }^{42}$. Relacja herbu królewskiego i kanclerskiego ma więc charakter odzwierciedlający bliską współpracę monarchy i możnego.

Herb Ciołek na sklepieniu kościoła chodelskiego musi jednak uosabiać także innych przedstawicieli rodu, na co wskazują pozostałe herby wymalowane na sklepieniu. Oto bowiem herb Rawa odnosi się zapewne do babki ojczystej Samuela - Katarzyny, małżonki Jana, podsędka lubelskiego w latach 1462-1481, która być może dożyła jeszcze początku XVI wieku $^{43}$. Z kolei herby umieszczone $\mathrm{w}$ bocznych partiach sklepienia odnoszą się do matki Samuela - Jadwigi z Podlodowskich herbu Janina, małżonki Bernarda Maciejowskiego, założyciela miasta (1517), podsędka, następnie sędziego lubelskiego (od 1512 roku), wreszcie kasztelana lubelskiego w latach 1535-154344. To z jego inicjatywy, ale pewnie nie bez rady syna Samuela, w 1541 roku biskup krakowski Piotr Gamrat podniósł kościół parafialny do rangi prepozytury. Plebanowi w randze prepozyta towarzyszyło odtąd sześciu mansjonarzy i bakałarz ${ }^{45}$. Bernard zmarł w 1543 roku, data śmierci jego żony - Jadwigi - nie jest znana (il. 1d, 7).

Po śmierci Bernarda miasto odziedziczyli jego dwaj synowie - Stanisław (zm. 1563) oraz Bernard (zm. 1551). Zapewne ten ostatni, tak jak i ojciec, kasztelan lubelski oraz jego druga żona - Elżbieta z Kamienieckich - zostali upamiętnieni renesansowym nagrobkiem, z którego do dziś

cyjne w dziedzinie architektury określa znakomita i wyjątkowa, niestety słabo zachowana willa w podkrakowskim Prądniku - zob. M. Sobala, Początki nowożytnej architektury rezydencjonalnej $w$ Polsce na przykładzie rezydencji biskupów i kanoników krakowskich $w$ pierwszej polowie XVI wieku, Studia nad sztuka renesansu i baroku, t. 11, Tradycja $i$ innowacje $w$ sztuce nowożytnej, red. I. Rolska, K. Gombin, s. 225-236, Idem, Rezydencja biskupów krakowskich na Prądniku, „Rocznik Krakowski” 75, 2009, s. 43-69.

${ }^{42}$ W. Dworzaczek, op. cit., s. 66 i 67.

${ }^{43}$ H. Kowalska, op. cit., s. 47.

44 Ibidem, s. 47-48.

45 Zob.: www.barbaragolofit.republika.pl/chodel.html (dostęp: 29.08.2014). 
pozostały jedynie marmurowe płyty z wizerunkami zmarłych. W każdym razie w genealogii Maciejowskich z połowy XVI wieku herb Pilawa można połączyć jedynie z Elżbietą z Kamienieckich, drugą żoną Bernarda ${ }^{46}$ (il. 7). W tej sytuacji kolejny z herbów towarzyszących Ciołkowi powinien odnosić się do żony drugiego z dziedziców miasta, Stanisława Maciejowskiego, marszałka koronnego i kasztelana sandomierskiego. I tak jest w rzeczy samej - około 1547 roku poślubił on Annę ze Stojanic Czuryłównę herbu Korczak ${ }^{47}$.

Oprócz niewielkiej tarczy z gmerkiem, który najprawdopodobniej trzeba uznać za znak osobisty tutejszego plebana-prepozyta z połowy XVI wieku, do identyfikacji pozostał już tylko herb Poraj - ledwie dziś czytelny. W kontekście genealogii rodu Maciejowskich w XVI wieku nie daje się on połączyć z żadną konkretną postacią. Ale i dla tej sytuacji można znaleźć logiczne wytłumaczenie. Znamienne jest bowiem, że wyłącznie ta tarcza nie uzyskała ozdobnych wycięć na krawędziach. Jest prosta i mniejsza od pozostałych (il. 1d). Skoro więc różni się wyglądem, mogła zostać przemalowana. Przypuszczam, że tak właśnie się stało, a powody ku temu miał pleban Stanisław Korzeniowski, który swe inicjały i herb Poraj kazał umieścić na fundowanej w 1616 chrzcielnicy ${ }^{48}$ (il. 8d). Zapewne z tego czasu pochodzi też malowana dekoracja łuku tęczowego, co pośrednio zdaje się poświadczać możliwość ingerencji w pierwotną dekorację malarską prezbiterium. Jeśli domysł o domalowaniu herbu Poraj dopiero w początkach XVII wieku jest zasadny, to trzeba założyć, że zastąpił on starszy herb, który pojawił się tu w połowie XVI wieku z racji rodowych koligacji Maciejowskich. Przypuszczam, że w miejscu tym widniał herb Nałęcz odnoszący się do Jana Leżeńskiego, starosty przedborskiego, męża Urszuli Maciejowskiej, córki Bernarda i Jadwigi - założycieli miasta, a siostry biskupa Samuela oraz dziedziców Chodla po 1543 roku - Bernarda i Stanisława ${ }^{49}$ (il. 7).

Przedstawione wyżej bogate programy heraldyczne dekorujące kościoły w Kraśniku i Chodlu należą do najstarszych zachowanych na terenie Lubelszczyzny sposobów manifestacji dumy rodowej w przestrzeniach sakralnych. Przebudowywanemu w XVI wieku kościołowi w Kraśniku oraz współczesnej mu świątyni z Chodla nadano funkcję rodowych nekropolii. Obydwie budowle uzyskały taki status w latach 40. XVI stule-

46 J. Dzięgielewski, J. Maciszewski, Maciejowski Bernard h. Ciołek (1548-1608), (w:) Polski Słownik Biograficzny, t. 19/1, z. 80, Wrocław-Warszawa-Kraków... 1974, s. 48.

${ }^{47}$ H. Kowalska, Maciejowski Stanisław h. Ciołek (zm. 1563), (w:) Polski Stownik Biograficzny, t. 19/1, z. 80, Wrocław-Warszawa-Kraków... 1974, s. 69-71.

48 Katalog zabythów..., t. 8, z. 1, s. 5.

${ }^{49}$ H. Kowalska, Maciejowski Bernard ..., s. 48. 
cia. Jest to czas, gdy w powstałym w 1475 roku województwie lubelskim dokonał się już proces wyodrębnienia lokalnych elit. Ich przedstawiciele wtedy także zaczęli odgrywać znaczącą rolę w hierarchii urzędów koronnych. W procesie rozwoju stylowego sztuki w Polsce okres ten przypada na niezwykle interesujący czas koegzystencji stylistycznej form późnogotyckich i wczesnorenesansowych. $Z$ podobnym zjawiskiem $w$ tym regionie spotkać się można jeszcze w kościele w Stężycy, cerkwi zamkowej w Kodniu, wieży mieszkalnej w Wojciechowie, a także w niektórych świątyniach Lublina. W tym kontekście obie prezentowane wyżej świątynie stanowią - jak sądzę - wymowne świadectwo awansu Lubelszczyzny jako terytorium kreatywnego i coraz bardziej istotnego $\mathrm{z}$ punktu widzenia rozwoju sztuki na ziemiach polskich.

\section{HERALDIC PROGRAMS IN THE DECORATIONS OF PARISH CHURCHES IN KRAŚNIK AND CHODEL}

\section{Summary}

The heraldic decoration of the church of the Regular Canons in Kraśnik reflects the chronology of its construction and transformations. The oldest, fifteenth-century coats of arms have been preserved in the sacristy and they refer to the founders of the church and monastery, the Tęczyńskis of Rabsztyn: Andrzej (d. 1461) and his son Jan (d. 1499) - coat of arms Topór, and Andrzej's mother, Anna, daughter of Dymitr of Goraj (d. 1441) - coat of arms Korczak. The coat of arms Topór on the support should be associated with Rector Jan Kaliński whose distinguished role played in the church's construction was commemorated by Jan Długosz. The coats of arms on the façade of the southern porch - Topór, Korczak, Leliwa, and Rawa - until now have been dated as fifteenth-century and associated with Jan Tęczyński (d. 1499). Indeed, they refer to the founder of the monastery but they were executed in the $16^{\text {th }}$ century during the church's modernization undertaken by Gabriel Tęczyński (d. 1552) of a different branch of the Tęczyński family, which purchased the Krasiczyn property in 1510. In that case, the coat of arms Topór [Ax] is turned upside down, possibly to commemorate the end of the Tęczyńskis of Rabsztyn family branch. The other coats of arms can be identified with individuals involved in the reconstruction of the church in the second quarter of the $16^{\text {th }}$ century. Topór and Pilawa on the vault of the northern aisle refer to husband and wife - Jan Gabriel Tęczyński (d. 1552) and Anna of Kamieniec (d. 1554?), and Topór and Korczak on the pulpit portal to another couple - Stanisław, Gabriel's son (d. 1560) and Anna nee Bohowitynowicz. Korczak on the parapet of the western gallery, located next to the coat of arms of the counts Tęczyński, Topór and Orzet (a two-headed eagle), should be associated with Jan Gabriel's daughter-in-law. Two coats of arms on the western façade, Topór and Lewart, refer to Jan Gabriel's sister who married Piotr Firlej, the voivode of 
Lublin. The coats of arms on the chancel keystones were frequently modified in the early modern times, but in the second quarter of the $16^{\text {th }}$ century they most likely repeated the program on the façade of the southern porch. In that set, the coat of arms Rawicz was replaced in 1604 with Jelita which represented the Zamoyski's who became new proprietors of the town.

The heraldic program on the vault of the church in Chodel was definitely painted in 1548-1550. The coats of arms placed next to the most important royal coat of arms of King Sigmund August with his initials "SA" refers to the most outstanding members of the Maciejowski family who founded both the town and the church. The coat of arms Ciolek, with the bishop's miter, commemorates the services of Samuel Maciejowski (d. 1550), the archbishop of Cracow and the Great Chancellor of the Crown, closely cooperating with the king, his father Bernard (d. 1543), and his brothers. The other coats of arms refer to the family connections of the Maciejowskis from the times when the construction of the church was coming to an end. Rawa refers to Samuel's paternal grandmother, Katarzyna, and Janina to Samuel's mother, Janina nee Podlodowski. Pilawa refers to Bernard's (d. 1551), Samuel's brother's wife, Elżbieta Kamieniecka, while Korczak to the other Samuel's brother's, Stanisław's (d. 1563) wife, Anna nee Czuryło. Next to a sign which probably refers to the Rector, there is Poraj, which does not fit the genealogy of the Maciejowskis, and which was probably painted on the vault in the early $17^{\text {th }}$ century to commemorate Rector Stanisław Korzeniowski who modernized the church. His coat of arms probably replaced Natecz from the mid-16 ${ }^{\text {th }}$ century, which indicated the marriage of Urszula, Samuel's sister, to Jan Leżeński.

The heraldic programs of the churches in Kraśnik and Chodel, made shortly before 1550, are the oldest manifestations of family pride of their kind, helping to date the construction and transformations of both buildings. 